\title{
Analisis Jumlah Pengangguran dan Ketenagakerjaan terhadap Keberadaan Usaha Mikro Kecil dan Menengah di Kabupaten Pasuruan
}

\author{
Muhammad Imam Syairozi \\ Fakultas Ekonomi Universitas Islam Lamongan \\ e-mail:syairoziimam@yahoo.ac.id \\ Ike Susanti \\ Fakultas Ekonomi Universitas Islam Lamongan \\ e-mail:Ik33susanti@gmail.com
}

\begin{abstract}
Abstrak
Dengan jumlah perusahaan UMKM saat ini 99,8 dari jumlah usaha ekonomi di Kabupaten Pasuruan mampu menyediakan lapangan kerja bagi 60.400 .000 atau 87,5\% dari total angkatan kerja secara keseluruhan, sehingga memberi peluang mengurangi tingkat pengangguran terbuka di Kabupaten Pasuruan. Tujuan penelitian ini adalah untuk menganalisis keadaan pengangguran dan lapangan kerja di bidangnya dan untuk menentukan peran UKM dalam menekan tingginya jumlah pengangguran di Kabupaten Pasuruan, serta untuk menentukan seberapa jauh pengaruh dari jumlah UKM dalam pekerjaan dan mengurangi pengangguran. Penelitian ini menggunakan analisis kuantitatif dengan pendekatan deskriptif. Sumber data yang diperoleh dari penelitian ini adalah data skunder dari BPS dan Dinas Koperasi Kabupaten Pasuruan. Metode pengujian menggunakan uji signifikansi. Dari hasil pengolahan data dalam penelitian menggunakan model multiple koefisien korelasi, diperoleh hasil bahwa jumlah pengangguran dan ketenagakerjaan memiliki efek signifikan terhadap keberadaan usaha mikro kecil dan menengah (UMKM) di Kabupaten Pasuruan.
\end{abstract}

Kata kunci: Pengangguran, ketenagakerjaan, UMKM.

\section{PENDAHULUAN}

Trend perkembangan kehidupan dunia ekonomi dan bisnis saat ini telah mengalami pergeseran paradigma, yaitu dari ekonomi berbasis sumber daya ke paradigma ekonomi berbasis pengetahuan ataupun kreativitas. Pergeseran tersebut terjadi karena paradigma ekonomi berbasis sumber daya yang selama ini dipandang cukup efektif dalam menghasilkan akselerasi pembangunan ekonomi dan pengembangan bisnis dianggap telah gagal mengadaptasi dan mengakomodasi berbagai perubahan lingkungan bisnis. Seiring dengan berjalannya waktu, kebutuhan masyarakat pun semakin mengalami peningkatan seperti sifat manusia yang tidak puas, pertambahan penduduk yang semakin meningkat, kemajuan ilmu teknologi dan informasi, perubahan taraf hidup yang semakin meningkat, dan derajat kebudayaan yang semakin maju hingga kebutuhan yang bervariasi dan beranekaragam membuat perkembangan ekonomi kreatif di arus pembangunan ekonomi modern ini harus membuat inovasi-inovasi sehingga membuat perkembangan ekonomi kreatif semakin meningkat.

Usaha mikro, kecil dan menengah (UMKM) selaku basis usaha kerakyatan merupakan alternatif yang tepat diterapkan di era globalisasi saat ini guna menyeimbangi dampak ekonomi global pada masyarakat. Fenomena krisis moneter Indonesia yang terjadi pada tahun 1997/1998 membuktikan bahwa perekonomian masyarakat masih mampu bertahan denga baik meski saat itu banyak usaha-usaha besar yang gulung tikar 
karena pailit didera pahitnya krisis yang terjadi. UMKM yang dapat bertahan pada badai krisis karena struktur keuangan yang tidak banyak bergantung seutuhnya pada perbankan, meski mereka tetap memanfaatkan jasa perbankan, baik untuk transaksi maupun untuk menjaga keamanan. Sebagian besar pelaku UMKM ini mengandalkan seluruh permodalannya sendiri yang bersumber pada tabungan pribadi, pinjaman dari bank, kerabat atau tetangga bahkan tak jarang yang perolehannya melalui pinjaman ke lembaga keuangan lainnya. Di sisi lain, UMKM yang umumnya padat karya ini juga mampu menyerap tenaga kerja dalam jumlah cukup besar. Jumlah UMKM saat ini berjumlah 99.8 dari total usaha ekonomi yang ada di Kabupaten Pasuruan. Berdasarkan data Badan Pusat Statistik (BPS), UMKM mampu menyerap tenaga kerja sebanyak 60,4 juta atau 87,5 persen dari total tenaga kerja keseluruhan (Indonesia).

Kenyataan ini telah membuktikan keberadaan UKMK sangat berpengaruh besar pada roda perekonomian nasional. Menilik pada data yang disajikan oleh BPS dapat dinterpretasikan bahwa secara umum UKMK memberikan kontribusi yang cukup besar dalam pertumbuhan perekonomian Kabupten Pasuruan khususnya. Hal ini dapat dilihat dari jumlah pertumbuhan UMKM di Kabupaten Pasuruan dalam kurun 3 tahun (2013-2015), yaitu tahun 2013 berjumlah 82.888 unit, tahun 2014 berjumlah 86.063 unit, dan tahun 2015 berjumlah 99.002. (BPS, 2015).

Namun demikian, kondisi UKM itu belum mampu menjadi solusi alternatif atas permasalahan saat ini, yaitu pengangguran. Dalam beberapa dekade terakhir masalah pengangguran dan ketenagakerjaan masih merupakan masalah besar yang dihadapi bangsa Indonesia secara umum, begitu pula Kabupaten Pasuruan khususnya. BPS (2015) mencatat jumlah pengangguran di Kabupaten Pasuruan pada tahun 2013 sebesar 100.586 jiwa, tahun 2014 sebesar 924.37 jiwa, dan tahun 2015 sebesar 429.00 jiwa. Sementara jumlah angkatan kerja pada tahun 2013 sebesar 399.60 jiwa, tahun 2014 sebesar 408.03 jiwa, dan tahun 2015 sebesar 401.25 jiwa. Secara data, kondisi yang sajikan cukup baik dimana tingkat penggangguran berkurang dalam kurun waktu 3 tahun terakhir. Meski demikian, besarnya jumlah atau angka pengangguran di Kabupaten Pasuruan ini digolongkan pengangguran terbuka dengan faktor penyebab adalah PHK.

Berdasarkan latar permasalahan yang telah diuraikan, maka rumusan masalah penelitian ini adalah: (1) Bagaimana keadaan pengangguran dan ketenagakerjaan di Kabupaten Pasuruan?; dan, (2) Bagaimana peran UMKM dalam menekan tingginya jumlah pengangguran terbuka yang terjadi di Kabupaten Pasuruan?. Tujuan penelitian ini adalah untuk: (1) menganalisis keadaan pengangguran dan ketenagakerjaan di wilayah Kabupaten Pasuruan; dan, (2) menganalisis peran UMKM dalam menekan tingginya jumlah pengangguran di Kabupaten Pasuruan.

\section{Pengertian UMKM}

Pengertian dari Usaha Mikro Kecil Menengah (UMKM) menurut Ketentuan Undang-Undang No. 20 Tahun 2008 tentang Usaha Kecil dan kemudian dilaksanakan lebih lanjut dengan Peraturan Pemerintah Nomor 44 Tahun 1997 tentang Kemitraan, di mana pengertian UMKM adalah sebagaimana diatur dalam Pasal 1 Undang-Undang Nomor 20 Tahun 2008 sebagai berikut:

1. Usaha Kecil adalah kegiatan ekonomi rakyat yang berskala kecil dan memenuhi kriteria kekayaan bersih atau hasil penjualan tahunan serta kepemilikan sebagaimana diatur dalam undang-undang ini.

2. Usaha Menengah dan Usaha Besar adalah kegiatan ekonomi yang mempunyai kriteria kekayaan bersih atau hasil penjualan tahunan lebih besar dari kekayaan bersih dan hasil penjualan tahunan usaha kecil.

Biro Pusat Statistik (BPS) Indonesia Tahun 2003 mendeskripsikan tipe perusahaan dengan: (a) jumlah tenaga kerja 1-4 orang digolongkan sebagai industri kerajinan dan rumah tangga; (b) perusahaan dengan tenaga kerja 5-19 orang sebagai industri kecil; (c) perusahaan dengan tenaga kerja 20-99 
orang sebagai industri sedang atau menengah; dan, (d) perusahaan dengan tenaga kerja lebih dari 100 orang sebagai industri besar.

Badan Pusat Statistik juga mendefinisikan UMKM menurut dua kategori, yaitu menurut omset serta menurut jumlah tenaga kerja. Menurut omset, usaha Kecil adalah usaha yang memiliki aset tetap kurang dari Rp. 200 juta dan omset per tahun kurang Rp. 1 milyar. Sementara, menurut jumlah tenaga kerja, usaha kecil adalah usaha yang memiliki tenaga kerja sebanyak 5 sampai 9 orang; dan, industri rumah tangga adalah industri yang memperkerjakan kurang dari lima orang.
UMKM adalah usaha yang mempunyai modal awal yang kecil, atau nilai kekayaan (aset) yang kecil dan jumlah pekerja yang kecil (terbatas), nilai modal (aset) atau jumlah pekerjanya sesuai dengan definisi yang diberikan oleh pemerintah atau institusi lain dengan tujuan tertentu (Sukirno, 2004). Jadi dapat disimpulakan Usaha Mikro Kecil Menengah (UMKM) adalah usaha yang masih dalam skala kecil dengan modal awal yang kecil dan jumlah pekerja yang masih terbatas. Sejumlah pengertian UMKM tersebut dirangkum dalam Tabel 1.

\section{Tabel 1. Pengertian UMKM dari Beberapa Organisasi}

\begin{tabular}{|c|c|c|c|}
\hline No. & Organisasi & Jenis Usaha & Keterangan Kriteria \\
\hline \multirow{3}{*}{1.} & \multirow{3}{*}{ Badan Pusat Statistik (BPS) } & Usaha Mikro & $\begin{array}{l}\text { Pekerja }<\text { orang termasuk keluarga } \\
\text { yang tidak dibayar }\end{array}$ \\
\hline & & Usaha Kecil & Pekerja 5 - 19 orang \\
\hline & & Usaha Menengah & Pekerja 20 - 99 orang \\
\hline \multirow[t]{2}{*}{2.} & \multirow[t]{2}{*}{ Menneg. Koperasi \& UKM } & Usaha Kecil (UU No. 9/1995) & $\begin{array}{l}\text { Aset }<\text { Rp. } 200 \text { Juta di luar tanah } \\
\text { dan bangunan. } \\
\text { Omzet tahunan }<\text { Rp. } 1 \text { Milyar }\end{array}$ \\
\hline & & $\begin{array}{l}\text { Usaha Menengah (Inpres } \\
10 / 1999)\end{array}$ & Aset Rp. 200 juta Rp. 10 Milyar \\
\hline \multirow{3}{*}{3.} & \multirow{3}{*}{ Bank Indonesia } & $\begin{array}{c}\text { Usaha Mikro (SK Dir BI No. } \\
\text { 31/24/KEP/DIR Tgl } 5 \text { Mei } \\
\text { 1998) }\end{array}$ & $\begin{array}{l}\text { Usaha yang dijalankan oleh rakyat } \\
\text { miskin atau mendekati miskin. } \\
\text { - Dimiliki oleh keluarga sumber- } \\
\text { daya lokal dan teknologi } \\
\text { sederhana. } \\
\text { - Lapangan usaha mudah untuk exit } \\
\text { dan entry. }\end{array}$ \\
\hline & & Usaha Kecil (UU No. 9/1995) & $\begin{array}{l}\text { Aset }<\text { Rp. } 200 \text { juta di luar tanah } \\
\text { dan bangunan } \\
\text { Omzet tahunan }<\text { Rp. } 1 \text { Milyar }\end{array}$ \\
\hline & & $\begin{array}{c}\text { Aset }<\text { Rp. } 200 \text { juta di luar } \\
\text { tanah dan bangunan: Omzet } \\
\text { tahunan }<\text { Rp. } 1 \text { Milyar }\end{array}$ & $\begin{array}{l}\text { - Aset }<\text { Rp. } 5 \text { Milyar untuk sektor } \\
\text { industry. } \\
\text { - Aset }<\text { Rp. } 600 \text { Juta di luar tanah } \\
\text { dan bangunan untuk manufacturing } \\
\text { - Omzet tahunan }<\text { Rp. } 3 \text { Milyar }\end{array}$ \\
\hline & Bank Dunia & $\begin{array}{l}\text { Usaha Mikro Kecil } \\
\text { Menengah }\end{array}$ & $\begin{array}{l}\text { - Pekerja }<20 \text { orang } \\
\text { - Pekerja } 20-150 \text { orang } \\
\text { - Aset }<\text { US } \$ 500 \text { ribu di luar tanah } \\
\text { dan bangunan }\end{array}$ \\
\hline
\end{tabular}

Sumber: www.menlh.go.id/usaha-kecil/top/kriteria.htm, Tahun 2018 


\section{Karakteristik UKM}

Dalam ketentuan UU No. 20 Tahun tentang Usaha Kecil, yang menjadi kriteria usaha kecil adalah: (1) memiliki kekayaan paling banyak $\mathrm{Rp}$ 200.000.000,- (tidak termasuk tanah dan bangunan tempat usaha); (2) memiliki hasil penjualan tahunan paling banyak Rp 1.000.000.000,-; (3) milik warga negara Indonesia; (4) berdiri sendiri, bukan merupakan anak perusahaan atau cabang perusahaan yang dimiliki, dikuasai atau berafiliasi baik langsung maupun tidak langsung dengan usaha menengah atau usaha besar; serta, (5) berbentuk usaha orang perorangan, badan usaha tidak berbadan hukum atau badan usaha yang berbadan hukum termasuk koperasi.

Selain itu, Sutojo mengemukakan ciriciri usaha kecil di Indonesia yaitu: (1) lebih dari setengah usaha didirikan sebagai pengembangan dari usaha kecil-kecilan; (2) selain masalah permodalan, masalah lain yang dihadapi oleh usaha kecil bervariasi tergantung dengan tingkat perkembangan usaha; (3) sebagian besar usaha kecil tidak mampu memenuhi persyaratan-persyaratan administrasi guna memperoleh bantuan bank; (4) hampir $60 \%$ dari usaha kecil masih menggunakan teknologi bersifat tradisional; (5) hampir setengah perusahaan kecil hanya menggunakan kapasitas terpasang kurang dari $60 \%$; (6) pangsa pasar usaha kecil cenderung menurun baik karena faktor kekurangan modal, kelemahan teknologi dan kelemahan manajerial; (7) hampir 70\% usaha kecil melakukan pemasaran langsung kepada konsumen; dan, (8) tingkat ketergantungan atas fasilitas-fasilitas pemerintah sangat besar.

Menurut Isono dkk. (2001), terdapat beberapa karakteristik yang menjadi ciri usaha kecil, yaitu: (1) mempunyai skala usaha kecil, baik modal, penggunaan tenaga kerja maupun orientasi pasar; (2) banyak berlokasi di wilayah pedesaan dan kota-kota atau daerah pinggiran kota besar; (3) status usaha milik pribadi atau keluarga; (4) sumber tenaga kerja berasal dari lingkungan sosial budaya (etnis geografis); (5) pola bekerja sering kali part time atau sebagai usaha sampingan dari kegiatan ekonomi lainnya; (6) memiliki kemampuan terbatas dalam mengadopsi teknologi, pengelolaan usaha serta tata administrasinya sendiri masih sederhana; dan (7) struktur permodalannya sangat tergantung pada fiskal aset, berarti kekurangan modal kerja dan sangat tergantung terhadap sumber modal sendiri serta lingkungan pribadinya.

\section{Pengertian Pengangguran}

Pengangguran merupakan suatu ukuran yang dilakukan jika seseorang tidak memiliki pekerjaan tetapi mereka sedang melakukan usaha secara aktif dalam empat minggu terakhir untuk mencari pekerjaan (Kaufman \& Hotchkiss, 1999). Pengangguran merupakan suatu keadaan dimana seseorang yang tergolong dalam angkatan kerja ingin mendapatkan pekerjaan tetapi mereka belum dapat memperoleh pekerjaan tersebut (Sukirno, 1994). Pengangguran dapat terjadi disebabkan oleh ketidakseimbangan pada pasar tenaga kerja, yang mana hal ini menunjukkan bahwa jumlah tenaga kerja yang ditawarkan melebihi jumlah tenaga kerja yang diminta.

Berdasarkan Gambar 1, dalam setiap periode, bagian $(s)$ dari orang-orang yang bekerja kehilangan pekerjaan mereka, dan sebagian dari para penganggur memperoleh pekerjaan. Tingkat pemutusan kerja dan perolehan kerja inilah yang menentukan tingkat pengangguran (Mankiw, 2003). Pengangguran terbuka dapat pula wujud sebagai akibat dari kegiatan ekonomi yang menurun, dari kemajuan teknologi yang mengurangi penggunaan tenaga kerja, atau sebagai akibat kemunduran perkembangan suatu industri. Pengangguran terbuka dapat juga dikatakan sebagai wujud dari kegiatan ekonomi yang menurun, dari kemajuan teknologi yang mengurangi penggunaan tenaga kerja, atau sebagai akibat dari kemunduran perkembangan suatu industri (Sukirno, 2004).

Pengangguran terbuka adalah pengangguran baik sukarela (mereka yang tidak mau bekerja karena mengharapkan pekerjaan lebih baik) maupun secara terpaksa (mereka yang mau/ingin bekerja tetapi tidak memperoleh pekerjaan). Pengangguran ini terjadi ada yang 
karena belum mendapat pekerjaan padahal telah berusaha secara maksimal dan ada juga yang karena malas mencari pekerjaan atau malas bekerja. Dapat disimpulkan pengertian dari pengangguran terbuka adalah seseorang yang termasuk dalam kelompok penduduk usia kerja yang selama periode tertentu tidak bekerja, dan bersedia menerima pekerjaan, serta sedang mencari pekerjaan.

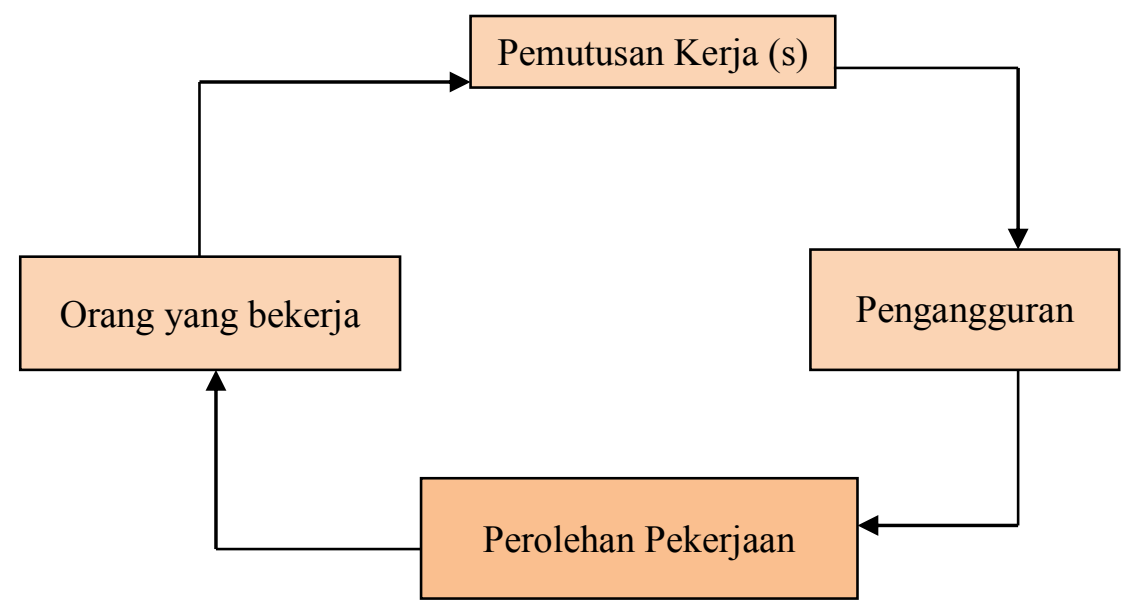

Sumber: Mankiw, tahun 2018.

\section{Gambar 1. Transisi menjadi Pekerja atau Pengangguran}

Pada Teori Klasik dijelaskan ada dua alasan penyebab terjadinya pengangguran, yaitu:

1. Kekakuan Tingkat Upah, dimana serikatserikat buruh tidak bersedia menerima tingkat upah yang lebih rendah, ketika mereka bersedia menerima tingkat upah yang lebih rendah, maka permintaan terhadap tenaga buruh akan meningkat, sehingga pengangguran dapat diturunkan.

2. Kekakuan yang kedua muncul dari pihak pengusaha besar, yang meningkat kekuatan monopolinya, sehingga mereka lebih leluasa menentukan tingkat harga pasar.

\section{Pengertian Ketenagakerjaan}

Tenaga Kerja adalah penduduk yang berada dalam usia kerja. Menurut Undang Undang Nomor 13 Tahun 2003 tentang ketenagakerjaan, yang disebut sebagai tenaga kerja adalah setiap orang yang mampu melakukan pekerjaan guna menghasilkan barang dan atau jasa baik untuk memenuhi kebutuhan sendiri maupun masyarakat. Dalam istilah Badan Pusat Statistik (2007), beberapa istilah ketenagakerjaan yang mesti dipahami sebagai dasar dalam memahami masalah itu di Indonesia, sebagai berikut: (a) Tingkat partisipasi angkatan kerja yang merupakan indikator yang dapat menggambarkan keadaan penduduk yang berumur 15 tahun ke atas yang berpartisipasi dalam kegiatan ekonomi; (b) Tingkat pengangguran terbuka; dan, (c) Penyerapan tenaga kerja yaitu mereka yang terserap diberbagai lapangan pekerjaan pada suatu periode.

Dalam teori ketenagakerjaan menurut BPS (2007) digunakan Konsep Dasar Angkatan Kerja (Standar Labour Force Concept) seperti yang digunakan dalam Survei Angkatan Kerja Nasional (Sakernas). Konsep ini merupakan konsep yang disarankan dan rekomendasikan International Labour Organization (ILO). Lebih lanjut disebutkan bahwa penduduk dibedakan atas usia kerja dan penduduk bukan usia kerja. Sedang penduduk usia kerja dibedakan atas dua kelompok, yaitu angkatan kerja dan bukan angkatan kerja. Angkatan kerja terdiri dari penduduk yang bekerja dan pengangguran. Sedangkan bukan angkatan kerja terdiri penduduk yang periode rujukan tidak mempunyai/melakukan aktivitas ekonomi, baik karena sekolah, mengurus rumah tangga atau lainnya (pensiun, penerima transfer/ 
kiriman, penerima deposito/bunga bank, jompo atau alasan yang lain).

\section{METODE PENELITIAN}

Ruang lingkup penelitian adalah menganalisis pengangguran dan ketenagakerjaan serta kaitannya tehadap keberadaan UMKM di Kabupaten Pasuruan dari tahun 2013-2015.

Penelitian ini menggunakan analisis kuantitatif dengan pendekatan deskriptif. Jenis data yang digunakan adalah data panel yang merupakan gabungan dari data timeseries dan cross-section dengan menggunakan periode tiga tahun (2013-2015) di Kabupaten Pasuruan. Sumber data primer diperoleh dari BPS dan dinas koperasi Kabupaten Pasuruan; selain juga bersumber dari studi baik literatur, jurnal maupun penelitian terdahulu.

Metode pengujianya menggunakan Uji signifikansi yang merupakan prosedur yang digunakan untuk menguji kebenaran atau kesalahan dari hasil hipotesis nol dari sampel. Pengolahan dataa menggunakan SPSS di uji statistik, dan juga uji hipotesis korelasi (R2) untuk melihat seberapa besar pengaruh jumlah pengangguran dan ketenagakerjaan terhadap usaha mikro kecil dan menengah (UMKM) di Kabupaten Pasuruan. Model persamaan regresi linear berganda yang digunakan dalam penelitian ini adalah:

$$
\mathrm{Y}=\alpha+\beta 1 \mathrm{X} 1+\beta 2 \mathrm{X} 2+\mu
$$

dimana $\mathrm{Y}$ adalah Usaha Mikro Kecil Menengah (UMKM); $\alpha$ adalah koefisien konstanta; $\beta 1$ adalah koefisien variabel pengangguran; $\beta 2$ adalah koefisien variabel ketenagakerjaan; $\mathrm{X} 1$ adalah variabel pengangguran; X2 adalah variabel ketenagakerjaan; serta, $\mu$ adalah term of error.

\section{HASIL ANALISIS}

\section{Keadaan Pengangguran dan Ketenaga- kerjaan di Kabupaten Pasuruan}

Secara geografis, Kabupaten Pasuruan diperkirakan terletak diantara: $2^{\circ} .27^{\prime}-2^{\circ} .47^{\prime}$

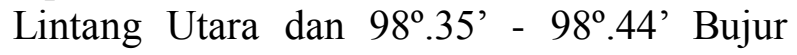
Timur. Kabupaten Pasuruan memiliki luas 26.510 Hektar atau 265,10 Km2 atau sama dengan 3,6 persen dari total luas wilayah provinsi Jawa Timur. Oleh karena itu, selain memiliki modal dasar pembangunan dengan jumlah penduduk dan letak geografis serta peranan regional yang relatif terus berkembang semakin besar dan strategis, namun Kabupaten Pasuruan juga memiliki keterbatasan ruang sebagai bagian dari daya dukung lingkungan.

Kabupaten Pasuruan pada saat ini sedang mengalami masa transisi demografi yang ditunjukkan dengan adanya proses pergeseran dari suatu keadaan dimana tingkat kelahiran dan kematian relatif tinggi menuju keadaan dimana tingkat kelahiran dan kematian semakin menurun. Dalam dimensi ketenagakerjaan, yang sering dilihat adalah angka pengangguran. Salah satu persoalan pokok pembangunan Kabupaten Pasuruan yang dihadapi selama periode 2013-2015 adalah relatif tingginya tingkat pengangguran terbuka. Munculnya pengangguran disebabkan laju pertumbuhan angkatan kerja yang jauh melampau laju pertumbuhan kesempatan kerja, sehingga mengakibatkan relatif masih tingginya angka pengangguran terbuka di Kabupaten Pasuruan. Indikator ketenagakerjaan diperoleh dari penduduk usia 15 tahun keatas yang dikelompokkan menjadi penduduk yang termasuk angkatan kerja, bekerja, pengangguran dan penduduk bukan angkatan kerja. Penduduk angkatan kerja terdiri dari mereka yang bekerja dan menganggur (termasuk didalamnya mereka yang mencari kerja). Sedangkan penduduk bukan angkatan kerja adalah mereka yang sekolah, mengurus rumah tangga dan lainnya.

Dalam membahas aspek ketenagakerjaan, pada umumnya yang paling sering dilihat adalah angka pengangguran. Salah satu persoalan pokok pembangunan yang dihadapi selama periode 2013-2015 adalah relatif masih tingginya tingkat pengangguran terbuka. Munculnya pengangguran ini disebabkan laju pertumbuhan angkatan kerja yang jauh melampaui laju pertumbuhan kesempatan kerja sehingga mengakibatkan relatif masih tingginya angka pengangguran terbuka di Kabupaten Pasuruan.

Faktor-faktor penyebab pengangguran secara global di Kabupaten Pasuruan adalah:

1. Jumlah angkatan kerja lebih besar dari pada kesempatan kerja yang tersedia. 
Tabel 2. Indikator Ketenagakerjaan di Kabupaten Pasuruan Tahun 2013-2015

\begin{tabular}{lccc}
\hline \multicolumn{1}{c}{ Jenis Indikator } & \multicolumn{3}{c}{ Tahun } \\
\cline { 2 - 4 } & 2013 & 2014 & 2015 \\
\hline 1. Angkatan Kerja & & \\
- Bekerja & 399.60 & 408.03 & 401.25 \\
- Pengangguran & 100.586 & 924.37 & 429.00 \\
\hline 2. Bukan Angkatan Kerja & & & \\
- Sekolah & 331.164 & 232.616 & 211.687 \\
- Mengurus Rumah Tangga & 273.575 & 300.779 & 285.450 \\
\hline
\end{tabular}

Sumber: BPS Kabupaten Pasuruan, Tahun 2018

2. Tingkat pendidikan yang rendah, sehingga berdampak pada sulitnya bersaing untuk mendapatkan pekerjaan.

3. Adanya budaya pilih-pilih pekerjaan (gengsi dan minder).

4. Latar belakang pendidikan tidak sesuai dengan pekerjaan yang disediakan.

5. Takut hidup susah yang berakibat malasnya mencari pekerjaan sehingga lebih suka menganggantungkan hidup pada orang tua dan pasanganya bila sudah menikah.

6. Tidak mau berwirausaha, umumnya seseorang yang baru lulus sekolah atau kuliah, mereka hanya terpaku dalam mencari pekerjaan, seolah itu tujuan mutlak

7. Kurangnya keterampilan, banyak mahasiswa atau lulusan SMA yang sudah mempunyai kriteria bekerja, namun dalam teknisnya keterampilanya masih kurang, sehingga susah dalam mencari pekerjaan.

Angka pengangguran ini perlu menjadi perhatian, baik yang berkaitan langsung dengan upaya setiap orang untuk memenuhi kebutuhan dasarnya, sehingga dapat hidup layak dan tidak menjadi beban sosial, maupun untuk mendorong mereka supaya dapat aktif secara ekonomi. Oleh karena itu, adalah kebijakan dasar dari Pemerintah Kabupaten Pasuruan selama periode 2007-2011, untuk mendorong terciptanya lapangan kerja baru, salah satunya melalui penanaman modal.

Indikator ketenagakerjaan di Kabupaten Pasuruan dapat dilihat dari jumlah penduduk usia 15 tahun ke atas yang dapat dikelompok- kan menjadi dua bagian, yaitu penduduk yang termasuk angkatan kerja dan penduduk yang bukan angkatan kerja. Penduduk angkatan kerja terdiri dari mereka yang berkerja dan penganggur (termasuk di dalamnya orang yang mencari kerja); sedangkan penduduk yang bukan angkatan kerja adalah mereka yang sedang sekolah, mengurus rumah tangga (IRT) dan lainnya.

Tabel 2 menunjukkan bahwa yang termasuk angkatan kerja selama periode 2013-2015 mengalami perkembangan yang fluktuatif. Hal ini terlihat dari jumlah angkatan kerja di Kabupaten Pasuruan pada tahun 2013 sebesar 339.60 orang, namun pada tahun 2014 meningkat sebesar 408.03, dan tahun 2015 meningkat lagi sebesar 401.25 orang. Hal ini mengindikasikan bahwa pada tahun 2014-2015 telah terjadi peningkatan kesadaran bagi masyarakat untuk melanjutkan pendidikan anaknya ke jenjang yang lebih tinggi.

\section{Peran UMKM terkait dengan Penyerapan Tenaga Kerja dan Mengurangi Jumlah Pengangguran}

Perkembangan usaha mikro kecil dan menengah (UMKM) di Kabupaten Pasuruan terus meningkat. Pertumbuhan dan perkembanganya dari tahun ke tahun menunjukan arah yang signifikan. Kita dapat melihat secara umum pertumbuhan perekonomian daerah tidak terlepas dari kontribusi UMKM. Hal ini dapat dilihat dari jumlah pertumbuhan UMKM yang ada di Kabupaten Pasuruan, yaitu pada tahun 2013 jumlah usaha mikro kecil dan menegah sebesar 82.888 unit; tahun 
2014 jumlah usaha mikro kecil dan menengah sebesar 86.063 unit; dan, tahun 2015 jumlah usaha kecil menengah meningkat sebesar 99.002 unit. Usaha mikro kecil dan menengah ini terdiri dari usaha makanan, minuman, kerajinan tangan, furnitur, jasa, dan percetakan. Jumlah usaha mikro kecil dan menengah (UMKM) saat ini berjumlah 99,8 persen dari total usaha ekonomi yang ada di Kabupaten Pasuruan. Berdasarkan data Badan Pusat Statistik (BPS), UMKM tersebut mampu menyerap tenaga kerja sebanyak 60,4 juta atau 87,5 persen dari total tenaga kerja keseluruhan.

Jika kita lihat dari jumlah usia, maka usia kisaran 26-35 tahun sebanyak (43.28\%). Selanjutnya diikuti oleh umur 36-45 tahun sebanyak (40.30\%). Untuk umur 17-25 tahun sebanyak (5.97\%). Untuk umur 46-55 tahun sebanyak (5.97\%). Untuk umur 56-65 tahun sebanyak (2.99\%). Sedangkan persentase terkecil berada pada kisaran $>65$ tahun sebanyak (1.49\%). Gambaran keadaan tersebut menjelaskan bahwa sebagian besar pengusaha UMKM termasuk dalam umur produktif. Deskriptif karakteristik sampel berdasarkan tingkat pendidikan dimana persentase terbanyak adalah SMA/Sederajat sebanyak (62.69\%). Selanjutnya SMP sebanyak (17.9\%). Untuk Sarjana (S1) sebanyak (13.43\%). Untuk SD sebanyak (4.49\%). Sedangkan persentase terkecil berada pada Diploma (D1, D2, D3) sebanyak (1.49\%). Ini menunjukan bahwa sebagian besar pengusaha UMKM masih didominasi oleh orang-orang yang lulusan di tingkat SMP dan SMA sederajat.

\section{Pengaruh Jumlah Pengangguran dan Ketenagakerjaan terhadap keberadaan UMKM}

Proses pengolahan data dalam penelitian ini menggunakan model regresi berganda, dimana hipotesis yang diajukan adalah:

- Ho: $\beta 1=\beta 2=0$; artinya jumlah pengangguran dan ketenagakerjaan tidak berpengaruh terhadap keberadaan usaha mikro kecil dan menengah (UMKM) di Kabupaten Pasuruan.

- Ho: $\beta 1 \neq \beta 2 \neq 0$; artinya jumlah pengangguran dan ketenagakerjaan berpengaruh signifikan terhadap keberadaan usaha mikro kecil dan menengah (UMKM) di Kabupaten Pasuruan.

Tabel 3. Pengujian Hipotesis Koefisien Korelasi Berganda $(R)$

\begin{tabular}{|c|c|c|c|c|c|c|c|}
\hline \multicolumn{8}{|c|}{ Coefficients $^{\mathrm{a}}$} \\
\hline \multirow[t]{5}{*}{ Model } & & $\begin{array}{l}\text { Unstandardized } \\
\text { Coefficients }\end{array}$ & & $\begin{array}{l}\text { Standardized } \\
\text { Coefficients }\end{array}$ & \multirow[t]{2}{*}{$\mathrm{t}$} & \multirow[t]{2}{*}{ Sig. } & \\
\hline & & B & Std. Error & Beta & & & \\
\hline & (Constant) & 66860.559 & .000 & & & & \\
\hline & Pengangguran & -0.276 & .000 & -1.010 & & & \\
\hline & Tenaga Kerja & 1.096 & .000 & .057 & & & \\
\hline \multicolumn{8}{|c|}{ Coefficients $^{\mathrm{a}}$} \\
\hline \multirow{2}{*}{ Model } & \multicolumn{3}{|c|}{$95.0 \%$ Confidence Interval for B } & & & & $\begin{array}{c}\text { Collinearity } \\
\text { Statistics }\end{array}$ \\
\hline & \multicolumn{2}{|c|}{ Lower Bound } & $\begin{array}{l}\text { Upper } \\
\text { Bound }\end{array}$ & Zero order & Partial & Part & Tolerance \\
\hline (Constant) & 66860.559 & 66860.559 & & & & & \\
\hline Pengangguran & -.276 & -.276 & -.998 & -1.000 & -.989 & .958 & \\
\hline Tenaga Kerja & 1.096 & 1.096 & -.150 & 1.000 & .056 & .958 & \\
\hline
\end{tabular}

Sumber: Data sekunder (diolah), Tahun 2018 
Tabel 4. Hasil $R$ Square

\begin{tabular}{|c|c|c|c|c|c|c|c|}
\hline \multirow[b]{2}{*}{ Model } & \multirow[b]{2}{*}{$\mathrm{R}$} & \multirow[b]{2}{*}{ R Square } & \multirow{2}{*}{$\begin{array}{l}\text { Adjusted } \\
\text { R Square }\end{array}$} & \multirow{2}{*}{$\begin{array}{l}\text { Std. Error of } \\
\text { the Estimate }\end{array}$} & \multicolumn{3}{|c|}{ Change Statistics } \\
\hline & & & & & $\begin{array}{l}\text { R Square } \\
\text { Change }\end{array}$ & F Change & df1 \\
\hline 1 & $1.000^{\mathrm{a}}$ & 1.000 & & & 1.000 & & 2 \\
\hline
\end{tabular}

Sumber: Data sekunder (diolah), Tahun 2018

Berdasarkan hasil perhitungan program SPSS pada Tabel 3 diperoleh nilai koefisien regresi untuk X1 sebesar -0,276 serta X2 sebesar 1,096; sedangkan nilai konstanta yaitu 66.860,559. Berdasarkan hasil perhitungan tersebut maka dapat diformulasian persamaan regresi linear berganda adalah:

$$
\begin{aligned}
& Y=a+b 1 X 1+b 2 X 2 \\
& Y=66.860,559+-0,276 X 1+1,096 X 2
\end{aligned}
$$

Konstanta (a) sebesar 66.860,559 menunjukkan bahwa apabila kedua variabel independen, yaitu pengangguran serta tenaga kerja, tidak mengalami perubahan atau bernilai tetap, maka keberadaan usaha mikro kecil dan menengah sebesar 66.860,559.

Selanjutnya, dilakukan proses analisis koefisien determinasi ( $R$ Square) yang diartikan seberapa besar kemampuan semua variabel independen dalam menjelaskan varians dari variabel dependen. Berdasarkan hasil dalam Tabel 4, diperoleh nilai $R$ Square sebesar 1,000 yang berarti kemampuan variabel-variabel pengangguran dan ketenagakerjaan dalam menjelaskan varians dari usaha mikro kecil dan menengah (UMKM) adalah 100,0\%. Hasil itu juga menunjukkan kemampuan faktor-faktor lain dalam menjelaskan varians dari UMKM adalah $0,0 \%$ karena rentang nilai $R$ Square yaitu 0 sampai 1 .

Proses pengujian hipotesis berdasarkan koefisien determinasi $\left(\mathrm{R}^{2}\right)$ adalah:

$\mathrm{R}^{2}=1,000$; maka

$$
\begin{aligned}
\text { F-hitung } & =R^{2}(N-k-1) k\left(1-R^{2}\right) \\
& =1,000(3-2-1) 2(1-1,000) \\
& =5,05
\end{aligned}
$$

dimana F-tabel $=5,54$; dengan kriteria hipotesis adalah:

- F-hitung $\leq \mathrm{F}$-tabel $=\mathrm{H}_{0}$ diterima

- F-hitung $\geq$ F-tabel $=\mathrm{H}_{0}$ ditolak, $\mathrm{H}_{\mathrm{a}}$ diterima
Berdasarkan perbandingan itu maka dapat dinyatakan bahwa variabel-variabel jumlah pengangguran dan ketenagakerjaan berpengaruh signifikan terhadap keberadaan usaha mikro kecil dan menengah (UMKM) di Kabupaten Pasuruan.

Selanjutnya dilakukan run test untuk menguji kemungkinan terdapatnya gangguan autokorelasi dalam data penelitian ini, dimana hasilnya ditunjukkan dalam Tabel 5. Kriteria pengujian adalah:

- Jika nilai Asymp. Sig (2-tailed) $\leq 0,05$; maka dinyatakan terdapat autokorelasi.

- Jika nilai Asymp. Sig (2-tailed) $\geq 0,05$; maka dinyatakan pada model tidak terdapat autokorelasi.

Berdasarkan hasil dalam Tabel 5, dimana dapat dilihat bahwa nilai Asymp. Sig (2-tailed) sebesar 0,724. Hasil ini menyatakan bahwa tidak terdapat gangguan autokorelasi pada data dari setiap variabel.

Tabel 5. Hasil Run Test

\begin{tabular}{ll}
\hline & $\begin{array}{l}\text { Mahalanobis } \\
\text { Distance }\end{array}$ \\
\hline Test Value $^{\mathrm{a}}$ & 1.33333 \\
Cases $<$ Test Value & 1 \\
Cases $>=$ Test Value & 2 \\
Total Cases & 3 \\
Number of Runs & 3 \\
Z & .354 \\
Asymp. Sig. (2- tailed) & .724 \\
\hline
\end{tabular}

Sumber: Data sekunder (diolah), Tahun 2018

\section{Pembahasan}

Keberadaan UMKM di Kabupaten Pasuruan sangat berpengaruh terhadap jumlah pengangguran dan penyerapan tenaga kerja. Oleh sebab itu, pemerintahan Kabupaten 
Pasuruan sebaiknya meningkatkan kepedulian terhadap UMKM dengan cara memberikan perhatian lebih terhadap perkembangannya melalui pemberian bantuan modal, seminar usaha, pelatihan dan izin usaha.

Selain upaya itu, pemerintah Kabupaten Pasuruan sebaiknya mengadakan pameran per tiga bulan di setiap kabupaten untuk promosi memperkenalkan produk-produk hasil home industry pada masyarakat luas agar mereka berminat untuk mengkonsumsi dan memakai produk yang dihasilkan, baik di dalam kota maupun di luar daerah, atau bahkan dapat melakukan ekspor ke berbagai negara.

Upaya-upaya tersebut dipandang akan berdampak pada peningkatan laba usaha, peningkatan output, dan perluasan usaha. Dengan adanya perluasan usaha, maka UMKM mampu menyerap tenaga kerja dan mengurangi jumlah pengangguran yang tersedia di Kabupaten Pasuruan.

\section{KESIMPULAN}

Berdasarkan hasil-hasil penelitian dan pembahasan, maka disimpulkan: (1) Hasil analisis menyatakan jumlah pengangguran dan ketenagakerjaan berpengaruh signifikan terhadap Usaha Mikro Kecil dan Menengah (UMKM) di wilayah Kabupaten Pasuruan; (2) UMKM adalah usaha skala kecil dengan modal awal yang kecil dan jumlah pekerja yang masih terbatas; (3) UKMK merupakan bentuk usaha yang bisa bertahan di dalam krisis ekonomi; (4) UMKM di Kabupaten Pasuruan saat ini berjumlah 99.8 dari total usaha ekonomi yang ada dan mampu menyerap tenaga kerja sebanyak 60,4 juta atau 87,5 persen dari total tenaga kerja keseluruhan, namun belum sepenuhnya mampu menyerap tenaga kerja di Kabupaten Pasuruan; (5) kehadiran UMKM mampu mengurangi pengangguran melalui perbaikan dan peningkatan perekonomian di Kabupaten Pasuruan baik di pusat maupun daerah; serta, (6) dengan adanya UMKM mampu menyerap tenaga kerja sehingga mengurangi tingkat pengangguran terbuka di wilayah Kabupaten Pasuruan.

Berdasarkan beberapa kesimpulan yang disampaikan, penelitian ini merekomendasi- kan beberapa hal. Pertama, dinilai perlu upaya penggalakan UKMK di wilayah Kabupaten Pasuruan melalui berbagai program UKMK, seperti: pelatihan, pembinaan, serta bantuan pemberian kredit usaha kreatif rakyat mulai dari pusat sampai ke daerah-daerah secara merata. Kedua, bagi kalangan akademisi agar membangun atmosfir wirausaha dikalangan mahasiswa melalui pembangunan konsep kreativas dilingkungan kampus (PT) secara masif agar terbentuk lulusan dengan kepribadian yang mandiri, inovasi, serta kreatif.

\section{DAFTAR PUSTAKA}

Aziz, F. 2013. Perkembangan Industri dan Ekonomi Kreatif di Indonesia. http://fauzanaziz.wordpress.com/2013/ 03/12/perkembangan-industri-danekonomikreatif-di-indonesia/

Badan Pusat Statistik (BPS). Kabupaten Pasuruan dalam angka 2007. Pasuruan.

Badan Pusat Statistik (BPS). Kabupaten Pasuruan dalam angka 2015. Pasuruan.

Bagus, P. 2012. Menilik Kesiapan Dunia Ketenagakerjaan Indonesia menghadapi MEA. Jurnal Rechts Vinding. Vol. 4, No. 2, hal. 35-37.

Buchari, A. 2006. Manajemen Pemasaran dan Pemasaran Jasa. Bandung: Alfabeta.

Dinas Koperasi Kabupaten Pasuruan dalam angka 2015. www.menlh.90.id/ usah kecil/top/kriteria.htm.

Isono, Sadoko dan Heryadi. 2001. Pengembangan Usaha Kecil. Bandung: Penerbit Yayasan Akagita.

Kaufman, B.E. dan Hotchkiss, J.L. .1999. The Economics of Labor Market. Yogyakarta: BPFE UGM.

Mahalli, K. 2008. Kesempatan Kerja dan Pertumbuhan Ekonomi Kota Medan. Jurnal Perencanaan \& Pengembangan Wilayah. Vol. 3, No. 3, hal. 1-7.

Mankiw, G. 2003. Teori Ekonomi. Jakarta: Erlangga. 
Peraturan Pemerintah Republik. UU Nomor 13 Tahun 2003 tentang Ketenagakerjaan. Jakarta.

Peraturan Pemerintah Republik. UU Nomor 20 Tahun 2008 tentang Usaha Mikro Kecil. Jakarta.

Sadono, S. 1994. Pengantar Makro Ekonomi. Jakarta: RajaGrafindo.

Supriyanto. 2006. Pemberdayaan Usaha Mikro, Kecil, dan Menengah (UMKM) sebagai Salah Satu Upaya Penanggulangan Kemiskinan. Junal JPIM. Vol. 3, No. 1, hal. 21-24.
Suryana, Y. 2013. Kewirausahaan (Pendekatan Karakteristik Wirausaha Sukses). Jakarta: Kencana Pranada Media Group.

Syairozi, M.I. dan Fatah, A. 2017. Analisis Pajak dan Variabel Makro Ekonomi terhadap Penerimaan Pajak Penghasilan. Prosiding. Seminar Nasional Sistem Informasi. Hal. 338-350.

Tambunan, T. 2012. Perekonomian Indonesia (Kajian Teoretis dan Analisis Empiris). Bogor: Penerbit Ghalia Indonesia. 